\title{
Donor Air Susu Ibu (ASI) dan Permasalahan Hukumnya serta Upaya Pencegahan Terjadinya Hubungan Kemahraman
}

\author{
Sabri Fataruba \\ Fakultas Hukum Universitas Pattimura, Ambon, Indonesia \\ E-mail: sabrifataruba@gmail.com
}

\begin{abstract}
Providing exclusive breastfeeding to babies is the duty of a mother, and the baby has the right to get exclusive breastfeeding from his mother for 6 (six) months, then perfecting it for 24 (twenty four) months or for 2 (two) years. However, not all biological mothers of children born can give breast milk to their children for various reasons. Therefore another mother is required to share (donate) her milk to meet the needs of the child's Mother's Milk. Sharing (donor) Mother's Milk is a noble act, because it can help children whose mothers for certain reasons cannot breastfeed their children. The legal provisions governing Mother's Milk donors are regulated in positive law as well as Islamic Law which is referenced from the word of Allah SWT, the hadith of the prophet Muhammad and Jumhur Ulama. A sincere effort to help other people's children to get Mother's Milk intake should be done by always paying attention to the applicable legal rules, because specifically for those who are Muslim according to their religious law, Mother's Milk donors can have implications for the occurrence of a relationship of friendship. To prevent the occurrence of marriage (marriage) due to the occurrence of the relationship of beauty, there needs to be synergy between government institutions, in this case the Ministry of Health, Ministry of Social Affairs, Ministry of Home Affairs, and Ministry of Religion. The manifestation of this synergy is in the form of policies (regulations) that must be immediately issued in accordance with the existing authority in each of these institutions which in essence is an effort to prevent the occurrence of marriage (marriage) due to the occurrence of the relationship of beauty. The policy (regulation) is a synergy between government institutions, in addition to preventing the occurrence of marriage (marriage) between certain people because of the relationship, also to prevent prospective Mother's Milk donors who have the disease, participate in donating breast milk so that endanger the health of the recipient donor
\end{abstract}

Keywords: Mother's Milk Donors, Legal Relations, Unclean to Merry. 


\section{A. PENDAhuluan.}

Memberikan ASI secara ekslusif kepada bayi adalah kewajiban seorang ibu, dan sang bayi berhak mendapatkan ASI ekslusif dari ibunya selama 6 (enam) bulan, selanjutnya menyempurnakannya selama 24 (dua puluh empat) bulan atau selama 2 (dua) tahun.

Namun demikian, tidak semua ibu kandung dari anak yang dilahirkan dapat memberikan ASI kepada anaknya karena berbagai alasan sebagai penyebabnya. Oleh karena itu keberadaan donor ASI sangat diperlukan dalam rangka memenuhi kebutuhan susu anak dari ibu yang bersangkutan.

Donor ASI terdiri dari 2 (dua) suku kata, yaitu kata "donor" dan "ASI". Secara istilah kata "donor" menurut kamus Bahasa Indonesia ialah "penderma atau pemberi sumbangan" ". Sedangkan ASI adalah akronim dari Air Susu Ibu.

Dengan demikian, jika kedua kata atau istilah tersebut dirangkai, maka dapat dirumuskan secara sederhana bahwa donor ASI adalah sumbangan air susu dari seorang ibu yang kelebihan air susunya kepada seorang anak (bayi) yang ibunya tidak dapat memberikan air susunya karena alasan-alasan tertentu.

Menurut Pasal 1 ayat (1) Peraturan Pemerintah Republik Indonesia Nomor 32 Tahun 2012 Tentang Pemberian Air Susu Ibu Eksklusif disebutkan bahwa, Air Susu Ibu yang selanjutnya disingkat ASI adalah cairan hasil sekresi kelenjar payudara ibu. Selanjutnya pada ayat (2)nya menyebutkan bahwa ASI eksklusif adalah ASI yang diberikan kepada bayi sejak lahir selama 6 (enam) bulan, tanpa menambah dan/atau mengganti dengan makanan lain. ASI adalah suatu emulsi lemak dalam larutan protein, laktosa dan garam-garam anorganik yang sekresi oleh kelenjar mamae ibu yang berguna sebagai makanan bagi bayi²

1 http://kamusbahasaindonesia.org/donor. (Diakses pada tanggal 10 April 20019).

2 Abdullah, Abdul Hakim Al Sayyid. (1993). Keutamaan Air susu Ibu, Jakarta: Fikahati Aneska, h. .30
Pemberian ASI ekslusif pada bayi sangat penting dan bermanfaat, baik bagi ibu maupun bagi bayinya. Adapun beberapa manfaat pemberian ASI ekslusif bagi ibu, yaitu mempercepat melangsingkan kembali si ibu setelah melahirkan. Hal ini disebabkan karena komponen utama ASI adalah lemak, sehingga dengan menyusui berarti si ibu menyalurkan lemak-lemak di tubuhnya kepada sang bayi. Isapan mulut bayi pada puting payudara ibu juga bakal menghasilkan hormon oksitosin yang bisa menghasilkan rangsangan ke saraf, selanjutnya rangsangan tersebut akan memberikan kontraksi di otot-otot tubuh ibu, jadi otot yang kendur juga bisa kembali kencang. ASI ekslusif untuk ibu juga memberikan manfaat antara lain, yaitu mengurangi pendarahan setelah melahirkan, mengurangi terjadinya anemia, mengurangi kemungkinan menderita kanker payudara dan kanker indung telur ${ }^{3}$.

Bagi bayi, ASI mengandung nutrisi lengkap, karbohidrat, protein, garam mineral, dan sebagai vitamin. Berbagai kandungan yang terdapat dalam ASI merupakan unsur sumber daya yang dibutuhkan bayi. ASI memiliki fungsi menjaga, memperkuat kekebalan tubuh bayi lebih baik karena ASI mengandung faktor-faktor protektif yang terdiri dari antibody, sel-sel darah putih, enzim dan harmoni tertentu ${ }^{4}$. Oleh karena itu, pemberian ASI pada bayi jelas sangat dianjurkan sebab ASI adalah merupakan makanan terbaik bagi bayi.

Namun demikian, hendaknya donor ASI dilakukan kepada bayi yang benarbenar tidak bisa mendapatkan air susu dari ibunya sendiri. Misalnya dalam keadaan :

1. Ibu meninggal setelah melahirkan;

2. Ibu mengidap hepatitis B;

3 ASI Ekslusif Atasi Tubuh Melar, Nyata, Rabu 11 Mei 2015,

4 ASI versus Susu Formula, Majalah Ayah Bunda, Edisi 25 - 8 Oktober, 2004, h.. 28 
3. Ibu positif mengidap HIV/AIDS;

4. Ibu yang sedang dalam proses pengobatan kanker;

5. Ibu dengan masalah jantung;

6. Ibu yang mengalami gangguan hormon.

Sedangkan syarat-syarat yang harus dipenuhi oleh seorang pendonor ASI, antara lain adalah :

1. Melahirkan anak dengan cara normal dan sehat;

2. ASI untuk anak sendiri sudah mencukupi dan melimpah;

3. Tidak sedang hamil;

4. Tidak merokok;

5. Tidak minum alkohol;

6. Tidak minum kopi/kafein (toleransi 150-200 ml/hari);

7. Tidak mengkonsumsi narkoba;

8. Bukan vegetarian;

9. Calon ibu donor dan suami tidak mengalami gejala yang mengarah ke penyakit HIV/AIDS, CMV (Citomegalovirus), HTL-1 (Human T-Lymphocvte Virus), Hepatitis, TBC, Sifilis ${ }^{5}$.

Fatwa MUI Nomor 28 Tahun 2013 Tentang Masalah-masalah yang Berkaitan Dengan Berbagi Air Susu Ibu (Istirdla') menetapkan bahwa ASI boleh untuk dibagi (didonor) harus memenuhi ketentuan sebagai berikut :

1. Ibu yang memberikan ASI harus sehat, baik fisik maupun mental;

2. Ibu tidak sedang hamil.

Kewajiban yang berupa perintah kepada ibu untuk memberikan ASI eksklusif dalam sejarah terdapat dalam QS. al Qasas (28) : 7, yang artinya : "Dan

5 http://yustianaoktavia17.blogspot.com / 2015 / 09 / makalah-agama-tentang-donor-asidan.html. (Diakses tanggal 28 April 2019)

${ }^{6}$ Fakhrudin, Arif dan Siti Irhamah (eds.), Al Hidayah: AL-Qur"an Tafsir ..., h. 357.

7 Hanafi Muchlis M. (ed.), Kesehatan Dalam Perspektif Al Quran..., h.. 81.

8 Ash-Shabuni, Muhammad Ali Terj. kami ilhamkan kepada ibunya Musa,"Susuilah dia (Musa)...". ${ }^{6}$

Berdasarkan ayat yang telah disebutkan di atas, dapatlah diketahui bahwa penyusuan Nabi Musa oleh ibunya bukanlah sesuatu yang muncul secara tibatiba, melainkan karena adanya petunjuk atau ilham dari Allah SWT kepada ibu Nabi Musa?

Perintah menyusui diungkapkan dengan bentuk kalam khabar (kalimat berita), gunanya adalah suatu keharusan yang sangat. Meskipun secara zahir kalimat itu adalah berita, tapi maknanya adalah perintah ${ }^{8}$. Sehubungan dengan penafsiran bahasa dengan pernyataan Imam Malik, bahwa ibu yang masih berstatus isteri wajib menyusui anaknya, atau dalam keadaan apabila anak tidak menerima ASI dari perempuan lain (jasa ibu susu), atau apabila ayah tidak ada ${ }^{9}$.

Selanjutnya QS. Al-Baqarah (2) : 233 menjabarkan mengenai wajibnya seorang ibu memberikan ASI eksklusifnya selama dua tahun atau menyerahkan anaknya dalam pengasuhan jasa ibu susuan jika mempunyai halangan dalam menyusui.

Persoalan yang berkaitan dengan donor ASI bukanlah hal baru, tetapi sudah lama dipraktekkan, bahkan dalam sejarah Nabi Muhammad SAW juga, beliau tidak hanya menyusu pada ibu kandungnya sendiri, melainkan disusukan pada ibu susu, yaitu seorang wanita Arab Badui yang bernama Halimah As-Sa'diyah ${ }^{10}$.

Di dataran Eropa, donor ASI ditandai dengan berdirnya Bank ASI di Wina Austria pada tahun 1909 dan kemudian merambah ke Jerman dan Boston Amerika Serikat dan sepuluh tahun kemudian berkembang ke berbagai negara, seperti di Amerika 154 buah,

Mua aeammal Hamidy dan Imron A. Manan. (2003). Terjemahan Tafsir Ayat Ahkam Ash-Shabuni, Surabaya: Bina Ilmu Offset, h. 290

9 Ibid, h. 293

10 Umam, Cholil. (1994). Agama Menjawab Tentang Berbagai Masalah Abad Modern, Cet. 2, Surabaya: Ampel Suci, , h.. 267 
Perancis 19 buah, India dan China di banyak rumah sakit serta Kuwait 1 buah ${ }^{11}$. Pada tahun 2009, tercatat bank ASI berkembang di 38 negara, dengan lebih dari 300 bank ASI. Perkembangan bank ASI tersebut juga merambah ke negaranegara berpenduduk muslim lainnya, selain Kuwait yang telah lebih dulu ada ${ }^{12}$.

Di Indonesia sendiri, saat ini hanya Rumah Sakit Cipto Mangun Kusumo (RSCM) yang memiliki bank penyimpanan ASI. Namun demikian, di luar sana terdapat individu-individu yang atas inisiatif sendiri-sendiri mendonorkan ASI-nya dengan menggunakan media online, padahal kita tahu bahwa persoalan donor ASI bukan hanya persoalan kemanusiaan dan kesehatan semata, tetapi di dalamnya terdapat masalah hukum yang berpotensi bagi terjadinya hubungan kemahraman, sehingga penting kiranya untuk dikaji masalah hukum tersebut serta upaya-upaya dalam rangka untuk mencegah terjadinya hubungan kemahraman.

Berdasarkan uraian latar belakang di atas maka penulis tertarik untuk mengkaji permasalahan yang dikaji "Bagaimana pengaturan donor ASI dan permasalahan hukumnya serta upaya pencegahan terjadinya hubungan kemahraman".

\section{B. PEMBAHASAN}

\section{ASI Dalam Perspektif Hukum Positif dan Hukum Islam}

\section{ASI Dalam Perspektif Hukum Positif}

Pasal 128 Undang-undang Nomor 36 Tahun 2009 Tentang Kesehatan menyebutkan bahwa Setiap bayi berhak mendapatkan air susu ibu eksklusif sejak dilahirkan selama 6 bulan, kecuali atas

\footnotetext{
${ }^{11}$ Pendapat Ulama Kontemporer Tentang Bank ASI, http://neddanoer.wordpress.com / 2011 / 06 / 11 pendapat-ulama-kontemporer-bank asi, (Diakses tanggal 18 Mei 2019).

12 http://holongmarinacom. blogspot.com / 2017 / 01 / bank-asi-dan-bank-sperma-
}

indikasi medis. Selama pemberian air susu ibu, pihak keluarga, pemerintah, pemerintah daerah, dan masyarakat, harus mendukung bayi secara penuh dengan penyediaan waktu dan fasilitas khusus. Penyediaan fasilitas khusus sebagaimana dimaksud pada ayat (2) diadakan di tempat kerja dan di tempat sarana umum ${ }^{13}$. Pasal 128 Undang-undang Nomor 36 Tahun 2009 Tentang Kesehatan tersebut memang tidak menyebutkan mengenai donor ASI melainkan hanya menekankan aspek hak dari bayi untuk mendapatkan ASI, sehingga perlu mendapat dukungan pihak keluarga, pemerintah, baik pusat maupun daerah serta masyarakat dalam penyediaan berbagai fasilitas yang dibutuhkan untuk keperluan dimaksud.

Pengaturan tentang donor ASI baru tampak ketika diterbitkannya Peraturan Pemerintah Nomor 32 Tahun 2012 Tentang Pemberian Air Susu Ibu Ekslusif. Di dalam Pasal 11 Peraturan Pemerintah (PP) Nomor 32 Tahun 2012 tersebut, disebutkan persyaratan-persyaratan khusus untuk para pendonor dan penerima donor ASI. Adapun persyaratanpersyaratan khusus dimaksud adalah sebagai berikut :

1) Permintaan ibu kandung atau keluarga bayi yang bersangkutan;

2) Identitas, agama, dan alamat pendonor ASI diketahui dengan jelas oleh ibu atau keluarga dari bayi penerima ASI;

3) Persetujuan pendonor ASI setelah mengetahui identitas bayi yang diberi ASI;

4) Pendonor ASI dalam kondisi kesehatan baik dan tidak mempunyai indikasi medis;

5) ASI tidak diperjualbelikan.

homoseksual.html, (Diakses tanggal 18 Mei 2019).

13 Rikasani, Ria Keajaiban ASI (Air Susu Ibu), Jakarta: Dunia Sehat, Tanpa Tahun Terbit, h. 164. 
Selain ketentuan di atas, secara implisit konsep ASI dalam kaitannya dengan larangan perkawinan diatur Undang-undang Nomor 1 Tahun 1974 Tentang Perkawinan. Dalam Pasal 8 Undang-undang Nomor 1 Tahun 1974 tersebut, disebutkan bahwa, Perkawinan dilarang antara dua orang yang :

1) Berhubungan darah dalan garis keturunan lurus ke bawah atau ke atas;

2) Berhubungan darah dalam garis keturunan menyamping yaitu antara saudara, antara seorang dengan seorang saudara orang tua dan antara seorang dengan saudara neneknya;

3) Berhubungan semenda, yaitu mertua, anak tiri, menantu dan ibu/bapak tiri;

4) Berhubungan susuan, anak susuan, saudara dan bibi/paman susuan;

5) Berhubungan saudara dengan isteri atau sebagai bibi atau kemenakan dari isteri, dalam hal seorang suami beristeri lebih dari seorang;

6) Yang mempunyai hubungan yang oleh agamanya atau peraturan lain yang berlaku dilarang kawin.

Dari ketentuan Pasal 8 Undangundang Nomor 1 Tahun 1974, khususnya pada angka 4 di atas memang tidak menyebutkan secara eksplisit tentang ASI, namun secara implisit dapat disebutkan atau dijelaskan hubungan susuan dapat mengakibatkan terjadinya larangan atau haramnya perkawinan.

\section{ASI dalam Perspektif Hukum Islam}

Berkaitan dengan ASI dalam perspektif Hukum Islam, penulis membaginya dalam 2 (dua) bagian, yaitu bagian pertama menyangkut ketentuan Hukum Islam berkaitan dengan ASI untuk kepentingan sang anak dan bagian kedua menyangkut dengan pemberian (donor) ASI yang berimplikasi hukum bagi hubungan kemahraman.
1. Ketentuan Hukum Islam berkaitan dengan ASI untuk kepentingan sang anak

a) Ketentuan yang bersumber dari firman Allah SWT

Ketentuan Hukum Islam berkaitan dengan ASI untuk kepentingan anak yang bersumber dari firman Allah SWT dapat dijumpai, diantaranya dalam al-Qur'an Surat al-Qasas (28) : 7, Surat at- Thalaq (65) : 6, Surat alBaqarah (2): 233. Dalam Surat al-Qasas (28) : 7 disebutkan, yang artinya: "Dan kami ilhamkan kepada ibunya Musa,"Susuilah dia (Musa)....." Sementara dalam Surat at-thalaq (65): 6) disebutkan, yang artinya:

"...kemudian jika mereka menyusukan (anak-anakmu), maka berikanlah mereka upahnya, dan musyarakanlah diantara kamu (segala sesuatu) dengan baik; dan jika kamu menemui kesulitan, maka perempuan lain boleh menyusukan (anak itu) untuknya".

Sedangkan dalam Surat alBaqarah (2) : 233 disebutkan, yang artinya : "Para ibu hendaklah menyusukan anakanaknya selama dua tahun penuh ...",

Ketiga ketentuan menyangkut dengan pentingnya ASI bagi anak yang telah disebutkan dalam al-Qur' an Surat al-Qasas (28) : 7, Surat at- Thalaq (65) : 6 dan Surat al-Baqarah (2) : 233 sebagaimana telah disebutkan di atas dapat diambil maksud dan intisari bahwa, anak itu dianjurkan disusui selama 2 (dua) tahun penuh, namun demikian apabila ibunya 
menemui kesulitan, maka perempuan lain boleh menyusukan anak itu untuknya dengan memberikan upah kepada perempuan lain yang menyusukan tersebut sesuai dengan hasil musyawarah yang telah disepakati diantara mereka, tentunya upah tersebut tidak untuk komersialisasi atau diperjualbelikan, tetapi diperoleh sebagai jasa pengasuhan anak.

b) Ketentuan yang bersumber dari Hadis Nabi Muhammad SAW Adapun ketentuan Hukum Islam yang berkaitan dengan ASI untuk kepentingan anak yang bersumber dari Hadis Nabi Muhammad SAW, yaitu : Hadis Riwayat Abu Dawud, yang artinya "Dari Ibnu Mas"ud Radhiyallahu Anhu bahwa Rasulullah Shallallahu Alaihi wa Sallam bersabda, "Tidak ada penyusuan kecuali yang menguatkan tulang dan menumbuhkan daging".

Selain itu, Hadis Riwayat alTarmidzi, yang artinya Tidak ada persusuan kecuali yang membuat usus terbuka (kenyang), yaitu sebelum usia dua tahun (HR al-Tirmidzi dan dihasankan olehnya).

2. Pemberian (Donor) ASI yang berimplikasi hukum bagi hubungan kemahraman

a) Ketentuan yang bersumber dari firman Allah SWT

Pemberian (donor) ASI yang berimplikasi hukum bagi hubungan kemahraman yang bersumber dari firman Allah SWT, yakni dalam al-Qur'an Surat an-Nisaa (4) : 23 menyebutkan, yang artinya “..... Dan ibu-ibumu yang menyusui kamu; saudara perempuan sepersusuan....".

Firman Allah yang terdapat dalam al-Qur'an Surat an-Nisaa (4) : 23 ini menunjukkan bahwa ibu yang menyusui berkedudukan sama dengan ibu kandung, demikian pula halnya dengan saudara sepersusuan sama dengan saudara kandung serta suami dari ibu susuan menjadi ayah kandung dari anak yang disusu isterinya tersebut. Dalam al-Qur'an Surat an-Nisaa (4) : 23 ini juga menjelaskan bahwa dalam konsep raḍlā' (persusuan) juga ada konsekuensi hukum jika menggunakan jasa ibu susuan yakni ketentuan hukum haramnya menikahi ibu susuan dan saudara perempuan sesusuan.

Untuk lebih jelasnya tentang siapa-siapa saja yang diharamkan untuk dinikahi berdasarkan konsep radla' ini, maka berdasarkan QS. AnNisa ${ }^{e e}$ (4) : 23 tersebut dijabarkannya lebih lanjut bahwa, yang diharamkan adalah, menikahi ibu-ibumu, anakanakmu yang perempuan, saudara-saudaramu yang perempuan, saudara-saudara ayahmu yang perempuan, saudara-saudara ibumu yang perempuan, anak-anak perempuan dari saudarasaudaramu yang laki-laki, anakanak perempuan dari saudarasaudaramu yang perempuan, ibu-ibumu yang menyusui kamu, saudara-saudara perempuanmu sesusuan.

b) Ketentuan yang bersumber dari Hadis Nabi Muhammad SAW dan Jumhur Ulama.

Hadis Nabi Muhammad SAW dan Jumhur Ulama yang 
berkaitan dengan pemberian (donor) ASI yang berimplikasi hukum bagi hubungan kemahraman memang relatif banyak.

Namun demikian, dalam penulisan ini, penulis hanya merujuk pada beberapa hadis dan Jumhur Ulama yang dirujuk oleh MUI melalui Fatwanya Nomor 28 Tahun 2013 Tentang Seputar Donor Air Susu Ibu (Istrdla'), yang dapat dikemukakan sebagai berikut :

1) Ketentuan yang bersumber dari Hadis Nabi Muhammad SAW

Adapun ketentuan yang bersumber dari Hadis Nabi Muhammad SAW tentang pemberian (donor) ASI yang berimplikasi hukum bagi hubungan kemahraman, yaitu Hadis Nabi Muhammad SAW yang artinya: "Diharamkan (untuk dinikahi) akibat persusuan apa-apa yang diharamkan (untuk dinikahi) dari nasab/hubungan keluarga" (HR Bukhari, Kitab Al-Syahadaat Bab Al-Syahadatu Ala Al-Ansaab ; Muslim, Kitab Al-Radhaa' Bab Yakhrumu Min Al-Radhaa' Maa Yakhrumu Min Al-Wilaadah).

Sesungguhnya persusuan (yang menimbulkanm hukum radla') hanyalah di masa anak membutuhkan ASI sebagai makanan pokok (HR Bukhari, Kitab AlSyahaadah Bab Al-Syahaadah ala Al-Ansaab dan Kitab Al-Nikaah Bab Man Qolaa La Radhaa'a Ba'da Hawlaini ; (H.R. Muslim, Kitab AlRadhaa' Bab Innamaa Al-Radhaa' min Al-Majaa'ah).

Dari Aisyah ra ia berkata: Dahulu, dalam apa yang diturunkan dari alQuran (mengatur bahwa) sebanyak sepuluh kali susuan yang diketahui yang menyebabkan keharaman, kemudian dinasakh (dihapus dan diganti) dengan lima kali susuan yang diketahui, kemudian Nabi saw wafat dan itulah yang terbaca di dalam al-Quran" (HR. Muslim).
2) Ketentuan yang bersumber dari Jumhur Ulama

Berkaitan dengan ketentuan yang bersumber dari Jumhur Ulama, maka Fatwa MUI Nomor 28 Tahun 2013 Tentang Seputar Donor Air Susu Ibu (Istrdla') merujuk pada beberapa pendapat ulama sebagai berikut :

a) Pendapat Zainudin bin Abdul Aziz Al-Malibari dalam Kitab Fathul Muin (Bab Nikah hal 101) yang menjelaskan tentang wanita mahram yang tidak teridentifikasi :

Andaikata ada wanita mahram tercampur pada sejumlah wanita yang sulit dihitung (didata satu persatu), misalnya jumlah mereka ada seribu orang (di antara seribu tadi terdapat wanita mahram yang sulit untuk dikenali bagi lelaki yang akan menikah), maka ia boleh menikahi siapapun di antara mereka yang disukainya, hingga jumlah mereka tinggal satu orang, pendapat ini adalah yang terkuat.

Tetapi jika ia (lelaki yang bersangkutan) mampu untuk menghitungnya guna mengetahui secara yakin wanita mana saja yang halal dinikahinya, atau wanita mahram tersebut bercampur dengan sejumlah wanita yang terbatas bilangannya, misalnya dua puluh bahkan sampai seratus orang wanita, maka ia tidak boleh menikahi seorangpun dari mereka (sebelum dia menyeleksi mana yang mahram dan mana yang bukan mahram).

Memang diperbolehkan ia menikahi di antara wanitawanita tersebut, jika secara pasti ia dapat membedakannya, misalnya wanita mahramnya berkulit hitam. Tetapi berada di 
antara penduduk yang berkulit tidak hitam, maka tidak haram baginya untuk menikahi wanita selain yang berkulit hitam tersebut.

b) Pendapat Al-Syiirazi dalam Kitab Al-Muhadzzab (4/587) :

Berlakunya hukum mahram (karena persusuan) dapat melalui proses al-wajur, yaitu memasukkan air susu ke tenggorokan tanpa proses menyusui langsung, dimana karena proses tersebut menyebabkan masuknya ASI kepada bayi seperti proses pemberian ASI secara langsung. Masuknya ASI tersebut berhubungan dengan proses alwajur yang juga berperan dalam pertumbuhan daging dan tulang seperti proses pemberian ASI langsung. Hukum mahram (karena persusuan) juga berlaku melalui proses $a l$-sa'uuth, yaitu memasukkan ASI melalui hidung, karena hal itu dapat membatalkan puasa, maka dapat dianalogikan sama seperti masuknya ASI melalui mulut.

c) Pendapat Ibnu Qudamah dalam Kitab Al-Mughni (11/313) :

Memasukkan ASI tanpa proses langsung namun menyebabkan ASI masuk ke dalam perut bayi, tidak berbeda dengan proses pemberian ASI secara langsung dalam menumbuhkembangkan daging dan tulang, sehingga hukum keduanya, baik pemberian ASI secara langsung atau tidak langsung adalah sama yaitu, berlakunya hukum mahram (karena persusuan).

d) Pendapat sebagian ulama seperti disebutkan dalam Kitab AlMughni (6/363)

Sebagian sahabat kami (ulama madzhab Hambali) berpendapat bahwa memperjualbelikan ASI adalah haram hukumnya. Pendapat ini sesuai dengan madzhab Abu Hanifah dan Malik. Alasan keharamannya karena ASI adalah benda cair yang keluar dari seorang wanita maka tidak boleh diperjualbelikan seperti keringat. Alasan lainnya, ASI adalah bagian dari manusia (yang tidak boleh diperjualbelikan).

e) Pendapat Muhammad Ibnu AlHasan dalam Kitab AlMabshuth (15/) :

Hak untuk memperoleh upah dari ASI karena sebab akad Ijarah menjadi dalil tidak diperbolehkannya melakukan jual beli ASI, sebagaimana kebolehan memperjualbelikan susu binatang menjadi dalil tidak diperbolehkannya melakukan akad Ijarah untuk memperoleh susu dari binatang tersebut.

Dengan merujuk pada firman Allah, Hadis Nabi Muhammad SAW serta Jumhur Ulama tersebut, maka dalam fatwanya MUI menetapkan bahwa :

a) Seorang ibu boleh memberikan ASI kepada anak yang bukan anak kandungnya. Demikian juga sebaliknya, seorang anak boleh menerima ASI dari ibu yang bukan ibu kandungnya sepanjang memenuhi ketentuan syar' $i$ :

b) Kebolehan memberikan dan menerima ASI harus memenuhi ketentuan sebagai berikut :

1) Ibu yang memberikan ASI harus sehat, baik fisik maupun mental;

2) Ibu tidak sedang hamil

c) Pemberian ASI sebagaimana dimaksud pada ketentuan angka 1 menyebabkan terjadinya mahram (haramnya terjadi pernikahan) akibat rad/a' (persusuan);

d) Mahram akibat persusuan sebagaimana pada angka 2 dibagi 
menjadi delapan kelompok sebagai berikut :

1) Ushulu Al-Syakhsi (pangkal atau induk keturunan seseorang), yaitu : Ibu susuan (donor ASI) dan Ibu dari Ibu susuan tersebut terus ke atas (nenek, buyut dan seterusnya);

2) Al-Furuu' Min Al-Radhaa' (keturunan dari anak susuan), yaitu : Anak susuan itu sendiri, kemudian anak dari anak susuan tersebut terus ke bawah (cucu, cicit dan seterusnya);

3) Furuu' Al-Abawaini min AlRadhaa' (keturunan dari orang tua susuan), yaitu : Anak-anak dari ibu susuan, kemudian anak-anak dari anak-anak ibu susuan tersebut terus ke bawah (cucu dan cicit);

4) Al-Furuu' Al-Mubaasyirah Min Al-Jaddi wa Al-Jaddati min AlRadhaa' (keturunan dari kakek dan nenek sesusuan), yaitu : Bibi sesusuan yang merupakan saudara kandung dari suami ibu donor ASI dan Bibi sesusuan yang merupakan saudara kandung dari ibu donor ASI. Adapun anak-anak mereka tidaklah menjadi mahram sebagaimana anak paman/bibi dari garis keturunan;

5) Uтmи Al-Zawjah wa Jaddaatiha min Al-Radhaa' (ibu sesusuan dari Istri dan nenek moyangnya), yaitu : Ibu susuan (pendonor ASI) dari istri, kemudian ibu dari ibu susuan istri sampai ke atas (nenek moyang);

6) Zawjatu Al-Abi wa Al-Jaddi min Al-Radhaa' (istri dari bapak sesusuan dan kakek moyangnya), yaitu : Istri dari suami ibu pendonor ASI (istri kedua, ketiga atau keempat dari suami ibu pendonor ASI), kemudian istri dari bapak suami ibu pendonor ASI sampai ke atas (istri kedua, ketiga atau keempat dari bapak suami ibu pendonor ASI sampai ke kakek moyangnya);

7) Zawjatu Al-Ibni wa Ibni Al-Ibni wa Ibni Al-Binti min AlRadhaa' (istri dari anak sesusuan dan istri dari cucu sesusuan serta anak laki dari anak perempuan sesusuan), yaitu : Istri dari anak sesusuan kemudian istri dari cucu sesusuan (istri dari anaknya anak sesusuan) dan seterusnya sampai ke bawah (cicit dst). Demikian pula istri dari anak laki dari anak perempuan sesusuan dan seterusnya sampai ke bawah (cucu, cicit dst);

8) Bintu Al-Zawjah min AlRadhaa' wa Banaatu Awlaadihaa (anak perempuan sesusuan dari istri dan cucu perempuan dari anak lakinya anak perempuan sesusuan dari Istri), yaitu : anak perempuan susuan dari istri (apabila istri memberi donor ASI kepada seorang anak perempuan, maka apabila suami dari istri tersebut telah melakukan hubungan suami istri -senggama- maka anak perempuan susuan istri tersebut menjadi mahram, tetapi bila suami tersebut belum melakukan senggama maka anak perempuan susuan istrinya tidak menjadi mahram). Demikian pula anak perempuan dari anak laki-lakinya anak perempuan susuan istri tersebut sampai ke bawah (cicit dan seterusnya).

e) Terjadinya mahram (haramnya terjadi pernikahan) akibat $\mathrm{rad} / \mathrm{a}^{\prime}$ (persusuan) jika :

1) Usia anak yang menerima susuan maksimal dua tahun qamariyah. 
2) Ibu pendonor ASI diketahui identitasnya secara jelas.

3) Jumlah ASI yang dikonsumsi sebanyak minimal lima kali persusuan.

4) Cara penyusuannya dilakukan baik secara langsung ke puting susu ibu (imtishash) maupun melalui perahan.

5) ASI yang dikonsumsi anak tersebut mengenyangkan.

f) Pemberian ASI yang menjadikan berlakunya hukum persusuan adalah masuknya ASI tersebut ke dalam perut seorang anak dalam usia antara 0 sampai 2 tahun dengan cara penyusuan langsung atau melalui perahan;

g) Seorang muslimah boleh memberikan ASI kepada bayi non muslim, karena pemberian ASI bagi bayi yang membutuhkan ASI tersebut adalah bagian dari kebaikan antar umat manusia.

Boleh memberikan dan menerima imbalan jasa dalam pelaksanaan donor ASI, dengan catatan; (i) tidak untuk komersialisasi atau diperjualbelikan; dan (ii) ujrah (upah) diperoleh sebagai jasa pengasuhan anak, bukan sebagai bentuk jual beli ASI.

\section{Upaya Pencegahan Terjadinya Hubungan Kemahraman}

Berdasarkan Penetapan MUI sebagaimana disebutkan di atas, maka jelaslah bahwa donor ASI sangat besar potensinya bagi terjadinya hubungan kemahraman. Untuk itu perlu kiranya menjadi perhatian, baik bagi pihak pendonor dan penerima donor maupun bagi pemerintah sebagai pembuat kebijakan. Hal ini penting kiranya agar di tengah upaya untuk saling berbuat baik, dalam hal ini memberi dan menerima ASI, tetapi karena tidak dilakukan secara bijaksana, maka akan membawa konsekuensi dan/atau implikasi hukum dikemudian hari, yaitu terjadinya pernikahan (perkawinan) diantara orangorang yang secara hukum tidak dibenarkan (dibolehkan) untuk melakukan pernikahan (perkawinan) karena terjadinya hubungan kemahraman.

Oleh karena itu, upaya nyata untuk mencegah terjadinya pernikahan (perkawinan) karena terjadinya hubungan kemahraman, maka menurut hemat penulis perlu adanya sinergitas antar lembaga pemerintah, dalam hal ini adalah Kementerian Kesehatan, Kementerian Sosial, Kementerian Dalam Negeri, dan Kementerian Agama.

Adapun wujud dari sinergitas tersebut adalah berupa kebijakan (peraturan) yang harus segera dikeluarkan sesuai dengan kewenangan yang ada pada masing-masing lembaga tersebut yang pada intinya adalah sebagai upaya untuk mencegah terjadinya pernikahan (perkawinan) karena terjadinya hubungan kemahraman.

Sehubungan dengan hal itu, maka lembaga pemerintah dimaksud perlu melakukan hal-hal sebagai berikut :

a. Kementerian Kesehatan

Yang harus dilakukan oleh Kementerian Kesehatan berkaitan dengan donor ASI, yaitu perlunya adanya peraturan yang dibuat oleh Kementerian Kesehatan. Adapun peraturan yang dibuat oleh Kementerian Kesehatan tersebut di dalamnya mengatur tentang larangan bagi calon pendonor ASI yang belum mendapatkan rekomendasi sehat dari tenaga kesehatan untuk mendonorkan ASInya. Tujuannya adalah agar orang yang mendonorkan ASI-nya tersebut dipastikan benar-benar terbebas dari penyakit, sehingga penerima ASI nantinya juga tidak ikut terjangkit atau tertular penyakit pendonor.

b. Kementerian Sosial

Upaya yang harus dilakukan oleh Kementerian Sosial, yaitu mengeluarkan peraturan yang 
mewajibkan pendonor ASI harus dilakukan melalui yayasan yang didirikan untuk tujuan itu, serta melarang pendonor perseorangan untuk mendonorkan ASI-nya apabila dalam keadaan tidak mendesak. Hal ini dimaksudkan untuk mempermudah pengawasan, terutama dari segi kesehatan pendonor, sebab apabila pendonor dalam keadaan mengidap penyakit, apalagi jenis penyakit tertentu yang bersifat menular, maka akan membahayakan kesehatan penerima donor, karena pasti akan terjangkit pula penyakit yang diidap pendonor, sehingga tujuan mulia pendonor untuk membantu penerima donor, justeru membawa kerugian bagi penerima donor, terutama dari segi kesehatannya.

Selain itu, dengan adanya pendonor ASI yang dilakukan melalui yayasan, akan mempermudah petugas kesehatan untuk memantau kesehatan pendonor maupun air susu yang didonornya.

Selanjutnya, di dalam peraturan tersebut juga diharapkan mewajibkan kepada pihak yayasan untuk mencatat secara lengkap bio data pendonor ASI maupun penerima ASI, meliputi : nama lengkap, alamat, pekerjaan, agama, golongan darah, serta garis keturunan, baik ke atas maupun ke bawah dari pendonor ASI maupun penerima donor, bila perlu dilakukan digitalisasi, sehingga apabila ada pihak-pihak yang memerlukan datadata tersebut, mudah untuk diakses. Donor ASI yang dilakukan secara perseorangan selain sangat menyulitkan bagi petugas kesehatan untuk memantau kesehatan pendonor maupun air susu yang didonornya, pada sisi yang lain bagi penganut agama Islam, dimana hukum agamanya menentukan bahwa donor ASI akan berimplikasi bagi adanya hubungan kemahraman, maka donor ASI yang dilakukan secara perseorangan menyulitkan dalam menentukan siapa-siapa yang mempunyai hubungan mahram (hubungan susuan yang mengharamkan pernikahan), apalagi jika pendonor sudah meninggal dunia atau masih hidup tetapi pindah tempat domisili.

c. Kementerian Dalam Negeri

Adapun peraturan yang harus dikeluarkan oleh Kementarian Dalam Negeri yang relevan dengan donor ASI, yaitu peraturan yang mewajibkan Dinas Kependudukan dan Catatan Sipil untuk membuat kolom khusus di dalam Kartu Keluarga, khusus bagi mereka yang beragama Islam, guna mencatat data lengkap mengenai identitas dari ibu susuan berikut garis keturunan, baik ke atas maupun ke bawah dari ibu susuan, bila ada ibu susuan dari anggota keluarga yang mengajukan permohonan Kartu Keluarga dimaksud, dengan adanya peraturan tersebut diharapkan mempermudah pihak lain, termasuk dalam hal ini KUA dalam menelusuri para pihak yang hendak mengajukan permohonan untuk menikah, apakah pihak tersebut mempunyai hubungan kemahraman atau hubungan susuan yang mengharamkan pernikahan atau tidak.

d. Kementerian Agama

Berkaitan dengan upaya pencegahan terjadinya hubungan kemahraman dalam hal terjadinya pernikahan (perkawinan), maka hal tersebut sesungguhnya tidak lepas dari tanggung jawab Kementerian Agama. Oleh karena itu, Kementerian Agama hendaknya mengeluarkan peraturan yang mewajibkan para pihak yang hendak mengajukan permohonan menikah (kawin) untuk melampirkan serta 
Kartu Keluarga sebagai salah satu syarat administrasi utama, sehingga apabila memang ada data ibu susuan di dalam kolom yang tersedia di Kartu Keluarga, maka KUA sebagai pelaksana Administrasi Perkawinan dapat dengan cepat dan mudah untuk memutuskan bahwa perkawinan tersebut dapat dilakukan atau tidak dapat dilakukan karena diantara kedua calon mempelai terdapat hubungan kemahraman.

\section{PE N U T P}

Berbagi air susu (donor) Air Susu Ibu (ASI) merupakan perbuatan mulia, karena dapat membantu anak yang ibunya karena alasan-alasan tertentu tidak dapat menyusui anaknya. Ketentuan hukum yang mengatur tentang donor ASI diatur dalam hukum positif maupun Hukum Islam yang dirujuk dari firman Allah SWT, hadis Nabi Muhammad SAW serta Jumhur Ulama.

Upaya tulus untuk membantu anak orang lain untuk mendapatkan asupan ASI hendaknya dilakukan dengan selalu memperhatikan kaidah-kaidah hukum yang berlaku, karena khusus bagi yang beragama Islam sesuai hukum agamanya, donor ASI dapat berimplikasi pada terjadinya hubungan kemahraman.

Mencegah terjadinya pernikahan (perkawinan) karena terjadinya hubungan kemahraman, maka perlu adanya sinergitas antar lembaga pemerintah, dalam hal ini adalah Kementerian Kesehatan, Kementerian Sosial, Kementerian Dalam Negeri, dan Kementerian Agama. Adapun wujud dari sinergitas tersebut adalah berupa kebijakan (peraturan) yang harus segera dikeluarkan sesuai dengan kewenangan yang ada pada masing-masing lembaga tersebut yang pada intinya adalah sebagai upaya untuk mencegah terjadinya pernikahan (perkawinan) karena terjadinya hubungan kemahraman.

Kebijakan (peraturan) yang bersifat sinergitas antara lembaga pemerintah tersebut, selain untuk mencegah terjadinya pernikahan (perkawinan) antara orang-orang tertentu karena adanya hubungan susuan, juga untuk mencegah calon pendonor ASI yang mengidap penyakit, turut serta mendonorkan ASInya sehingga membahayakan kesehatan penerima donor

\section{DAFTAR PUSTAKA}

Abdullah, Abdul Hakim Al Sayyid. (1993). Keutamaan Air susu Ibu, Fikahati Aneska, Jakarta, Fikahati Aneska.

Rikasani, Ria Keajaiban ASI (Air Susu $I b u)$, Dunia Sehat, Jakarta, Tanpa Tahun Terbit.

Umam, Cholil. (1994). Agama Menjawab Tentang Berbagai Masalah Abad Modern, Cet. 2, Surabaya: Ampel Suci.

\section{Lain-Lain}

ASI Ekslusif Atasi Tubuh Melar, Nyata, Rabu 11 Mei 2015.

http://kamusbahasaindonesia.org/donor. Majalah Ayah Bunda, ASI versus Susu Formula, Edisi 25 - 8 Oktober, 2004.

http://yustianaoktavia17.blogspot.com/20 15/09/makalah-agama-tentangdonor-asi-dan.html. Diakses tanggal 28 April 2019.

Pendapat Ulama Kontemporer Tentang Bank ASI, http://neddanoer.wordpress.com/20 11/06/11pendapat-ulamakontemporer-bank asi. 